\title{
QUALITY PROMISES. DO COMPANIES FOLLOW A STANDARD CODE OF CONDUCTS MODEL? THE CASE OF SPAS
}

\begin{abstract}
The aim of this paper is to analyze the ways of developing and fulfilling of quality promises as well as to explore whether these actions are formally constituted. Two European countries were chosen for the research in order to compare organizations from countries with different experiences with the implementation of quality management systems. Spain is an old EU country where QMS systems are widely implemented. According to the ISO survey Spain is on the 4th place in Europe in a number of organizations with ISO 9001 certificates. Poland is one of the countries with the average number of registered QMS, ranking 11 place in Europe with ISO 9001 certificates. For this purpose there has been researched seven case studies of spa organizations within the leisure industry from Poland and Spain (three and four respectively). The case studies illustrate the organizations' approach to manage quality promises. The case study method has been chosen due the specificity of the analyzed subject and the way of the business they run. The results show that all seven organizations have some mechanisms implemented to handle quality promises. The results also suggest that quality promises are widely used by organizations, but formalization of the promises through their recording in leaflets, on website or in other documents that are available for customers is not as common. Also, the analysis indicated that fulfillment of guiding principles from ISO 10001 are on a medium level and there are possibilities to improve them.
\end{abstract}

Keywords: service quality, customer satisfaction, quality promises, ISO 10001.

\section{INTRODUCTION}

Maintaining high level of quality and customer satisfaction is a significant challenge for many organizations today, including service organizations ${ }^{5}$. Moreover, there is an

${ }^{1}$ Dr inż. Piotr Kafel, The Department of Quality Management, Cracow University of Economics, Poland; e-mail: piotr.kafel@uek.krakow.pl.

2 Prof. Alexandra Simon, Business Department, Autonomous University of Barcelona, Spain.

${ }^{3}$ Dr inż. Paweł Nowicki ,The Department of Quality Management, Cracow University of Economics, Poland; e-mail: pawel.nowicki@uek.krakow.pl.

${ }^{4}$ Prof. Marti Casadesus, Organization, Business Management and Product Design Department, University of Girona, Spain.

${ }^{5}$ P. Kotler, K. Keller, Marketing Management, 12th ed, Prentice Hall, 2006; A. Simon, S. Karapetrovic, M. Casadesus, On the applications of ISO 10000 customer satisfaction standards in Catalonia, "International Journal of Advanced Quality", 41(1), 23-27, 2013. 
agreement that the quality of a service encounter is significant to business success or failure ${ }^{6}$.

The delivery of services in certain settings such as the Spas sector, the sector that this paper focuses on, involves high contact encounters with significant interaction among customers, staff and facilities ${ }^{7}$. The challenge for companies is to balance the need to treat customers as individuals with the requirements for routine and standardization. In order to achieve these goals and maintain satisfied customers in the organization, organizational performance evaluation measures of customer satisfaction need to be put in place. Managers need to learn about problems and take appropriate corrective actions to ensure that mistakes do not recur.

To convince clients about the high quality of services managers use code of conducts related to customer satisfaction, which are in this situation a customer promises made by an organization and related provisions. The promise or promises that are used by the organization for the purpose of maintaining and enhancing customer satisfaction and relate to the organization's products or the interaction of the organization with its existing or potential customers $^{8}$. There may be many different types of promises but for the purposes of this research and analysis, the only quality promise has been used. Quality promises can lead to satisfaction or dissatisfaction, pointing at problems or failures in internal processes. Fulfillment of quality promises give an opportunity to avoid losing profitable customers which experience unacceptable level of quality service.

One of the mechanisms that organizations have in order to enhance customer satisfaction and deal with dissatisfied customer is the implementation of code of conducts from the ISO 10000 series. This can be easily applied in any service organization, as they can be targeted on different "customers", for example, the clients of a spa, the employees or any other stakeholder relevant to the organization. The study of implementation of cods of conducts and of ISO 10000 standards in a specific sector, such as Spas, is a topic that has received very little attention so far. There could be also a link between an implementation of other ISO standards such as ISO 9001, ISO 14001, ISO 18000 that could be used as a background for implementation of ISO 10000 standards family, where there are a lot of different literature sources exist ${ }^{9}$, but this standards aiming a different goals. However the

${ }^{6}$ J.L. Crompton, L.L. Love, The Predictive Validity of Alternative Approaches of Evaluating Quality of a Festival, "Journal of Travel Research", 34, 11-24, 1995.

7 C.H. Lovelock, L. Wright, Principles of Service Marketing and Management, N.J., Prentice-Hall, 1999; P. Nowicki, A. Simon, P. Kafel, M. Casadesus, Recognition of customer satisfaction standards of ISO 10000 family by spa enterprises - a case study analysis, Revista TMQ, Techniques, Methodologies and Quality, 5, 91-105, 2014.

${ }^{8}$ ISO 10001 (2007), Quality Management - Customer Satisfaction - Guidelines for Codes of Conduct, International Organization for Standardization, Geneva, Switzerland.

9 J.A. Briscoe, S.E. Fawcett, R.H. Todd, The implementation and impact of ISO 9000 among small manufacturing enterprises, "Journal of Small Business Management", 43(3), 309-330, 2005; P. Sampaio, P. Saraiva \& A. Guimarães Rodrigues, ISO 9001 certification research: questions, answers and approaches, "International Journal of Quality \& Reliability Management", 26(1), 38-58, 2009; J.P. Mo, \& A.M. Chan, Strategy for the successful implementation of ISO 9000 in small and medium manufacturers, The TQM magazine, 9(2), 135-145, 1997; S. Urbonavicius, ISO system implementation in small and medium companies from new EU member countries: A tool of managerial and marketing benefits development, "Research in international business and finance", 19(3), 412-426, 2005; S.P. Chattopadhyay, Improving the speed of ISO 14000 implementation: 
structure of all those systems basis on PDCA scheme, the requirements of ISO 10000 standards family is a very little part of ISO 9001.

Hence, the objective of this investigation is to analyze the ways of developing and fulfilling quality promises as well as to explore whether these processes are formally constituted in terms of standards or other models for code of conducts e.g. ISO 10001.

The paper is structured as follows. First, a literature review on customer satisfaction, code of conduct and ISO 10000 standards is provided. Then, the methodology used for this investigation and the main results found are explained. The paper concludes with an analysis and a summary of the findings and the proposal of some implications and future research lines in the field.

\section{LITERATURE REVIEW}

\subsection{Customer satisfaction and quality promises}

In service industry such as hotels and spas, customer satisfaction is not only an important goal, it is also a vital marketing tool for attracting future customers and ensuring stronger market positions ${ }^{10}$. However, customers may not only voice their satisfaction but also their dissatisfaction, and recently, many studies have pointed out the need of investigation of customer complaints as an important customer voice ${ }^{11}$.

This study explores the use of code of conducts (e.g. quality promises) that are formally or informally directed to clients. It is a method to build a trust to the organization ${ }^{12}$. Promises made to customers must be taken very seriously. The focus must be on fulfilling these promises, instead of trying to find excuses or invoking special conditions when the firm is at fault; customers will not necessarily give service firms a second chance ${ }^{13}$. Failures in service delivery are unavoidable and recovery of such encounters represents a significant challenge for service organizations. When service failure occurs, customers experience disconfirmation and feel displeased ${ }^{14}$. In situations of service failure where trust has been

a framework for increasing productivity, "Managerial Auditing Journal", 16(1), 36-40, 2001; B. Poksinska, J. Jörn Dahlgaard \& J.A. Eklund, Implementing ISO 14000 in Sweden: motives, benefits and comparisons with ISO 9000, "International Journal of Quality \& Reliability Management”, 20(5), 585-606, 2003; C.Y. Chen, G.S. Wu, K.J. Chuang, C.M. Ma, A comparative analysis of the factors affecting the implementation of occupational health and safety management systems in the printed circuit board industry in Taiwan, "Journal of Loss Prevention in the Process Industries", 22(2), 210-215, 2009; P. Nowicki, P. Kafel, T. Sikora, Assessment of integrated management system policy, Economy and Management, Wydawnictwo Politechniki Białostockiej, $105-112,2012$.

10 X Luo, C. Homburg, Neglected outcomes of customer satisfaction, "Journal of Marketing", 71(2), 133-149, 2007.

${ }^{11} \mathrm{X}$ Luo, Consumer negative voice and firm-idiosyncratic stock returns, "Journal of Marketing", 71(3), 75-88, 2007.

${ }^{12}$ E. Schniter, R.M. Sheremeta, D. Sznycer, Building and rebuilding trust with promises and apologies, "Journal of Economic Behavior \& Organization", 94, 242-256, 2013.

${ }^{13}$ L. Fabien, Making promises: the power of engagement, "Journal of Services Marketing", Vol. 11(3), 206-214, 1997.

14 A.K. Smith, R.N. Bolton, J. Wagner, A model of customer satisfaction with service encounters involving failure and recovery, "Journal of Marketing Research", 36(3), 356-372, 1999. 
damaged, fast fulfilment of the promises simultaneously with appropriate apologies and explanations have been shown to elicit forgiveness ${ }^{15}$ and promote future trust $^{16}$.

\subsection{ISO 10000 series of standards for customer satisfaction}

As mentioned in the previous section, it is important that service organizations maintain high levels of quality and customer satisfaction. Product and service knowledge is one of the most important attributes for visiting particular $\mathrm{spa}^{17}$. Traditionally organizations have applied the ISO 9001 Quality Management System (QMS) standard for quality assurance for this purpose ${ }^{18}$. Instead of QMS, companies may develop their ideas and practices according to the schemes provided in the excellence models ${ }^{19}$. It is considered that the most popular excellence model in Europe is EFQM Excellence Model. Other most recognized organizational quality awards are the Malcolm Baldrige National Quality Award, the Deming Prize or the Australian Business Excellence Framework ${ }^{20}$. There are also quality standards designed especially for particular branches or industries. An example of that standard in leisure industry is The Q Tourist Quality Standard which implementation can bring an organization numerous benefits such as prestige, differentiation from competitors, enhanced internal efficiency, improved processes, customer satisfaction and publicity ${ }^{21}$. The scope of all mentioned above standards and prizes is very wide and include requirements such as: product realization, measurement, analysis and improvement, management responsibility and resource management ${ }^{22}$.

15 M.E. McCullough, K.C. Rachal, S.J. Sandage, E.L. Worthington, S.W. Brown, T.L. Hight, Interpersonal forgiving in close relationships. II. Theoretical elaboration and measurement, "Journal of Personality and Social Psychology", 75, 1586-1603, 1998; M. Girard, E. Mullet, S. Callahan, The mathematics of forgiveness, "American Journal of Psychology", 115, 351-375, 2002; E.C. Tomlinson, The impact of apologies and promises on post-violation trust: The mediating role of interactional justice, "International Journal of Conflict Management", 23(3), 224-247, 2012.

${ }^{16}$ D. De Cremer, E. van Dijk, M.M. Pillutla, Explaining unfair offers in ultimatum games and their effects on trust: an experimental approach, Business Ethics Quarterly, 20(1), 107-126, 2010.

17 D. Kucukusta, L. Pang, S. Chui, Inbound Travelers' Selection Criteria for Hotel Spas in Hong Kong, "Journal of Travel \& Tourism Marketing", 30(6), 557-576, 2013.

18 A. Simon, S. Karapetrovic, M. Casadesus, On the applications of ISO 10000 customer satisfaction standards in Catalonia, "International Journal of Advanced Quality", 41(1), 23-27, 2013.

19 A. Bayo-Moriones, J. Merino-Díaz-de-Cerio, S.A. Escamilla-de-León, R.M. Selvam, The impact of ISO 9000 and EFQM on the use of flexible work practices, International Journal of Production Economics, 130(1), 33-42, 2011; M. Martínez-Costa, A.R. Martínez-Lorente, T.Y. Choi, Simultaneous consideration of TQM and ISO 9000 on performance and motivation: an empirical study of Spanish companies, "International Journal of Production Economics", 113(1), 23-29, 2008.

${ }^{20}$ R.S. Ansoleaga, R.S., EFQM excellence model implementation in Metro Bilbao. Dyna 82, 6-8, 2007; P. Kafel, Normy wspomagajace systemy zarzadzania - wykorzystanie w organizacjach, ABC Jakości. Quality Review, 1(81), 15-19, 2015.

${ }^{21}$ M.C. Viada-Stenger, F. Balbastre-Benavent, A.M. Redondo-Cano, The implementation of a quality management system based on the $Q$ tourist quality standard. The case of hotel sector. Service Business, 4, 177-196, 2010.

22 ISO 9001 (2015). Quality Management Systems - Requirements, International Organization for Standardization, Geneva, Switzerland. 
However, there are standards which describe in more detail one selected issue such as complaints handling or code of conducts. The International Organization for Standardization (ISO) has developed three interrelated standards to manage quality and customer satisfaction $^{23}$ :

- Quality Management: Customer satisfaction. Guidelines for Codes of Conduct (ISO 10001:2007).

- Quality Management: Customer satisfaction. Guidelines for Complaints Handling in Organizations (ISO 10002:2004).

- Quality Management: Customer satisfaction. Guidelines for External Customer Dispute Resolution (ISO 10003:2007).

All above mentioned standards are compatible with ISO 9001 standard and support the objectives of QMS, but it is possible to implement them independently ${ }^{24}$.

In this paper, only a look at the ISO 10001 standard has been undertaken because it focuses on codes of conduct for organizations. ISO 10001 is intended to help organizations to develop customer satisfaction codes of conduct which are defined as promises to customers and related provisions used by organizations to address such issues as: product delivery within pre-determined time frames; product returns; handling of personal information of customers; advertising; pricing; fair trading; and stipulations concerning particular attributes of a product or its performance (ISO 10001). By establishing such codes of conduct, organizations are attempting to shape customer expectations in an effort to prevent complaints $^{25}$. The standard can be used by organizations regardless of type, size and product provided, and it is compatible with ISO 9001 and ISO 9004 and supports the objectives of these two standards ${ }^{26}$. The standard is structured according to seven guiding principles that help the organization in planning, designing, implementation, maintenance and improvement of the codes of conduct. According to those principles, sufficient resources for code processes should be available. Also, it helps organizations when the code is well publicized and easy available so that customers, employees and other interested parties are aware of it. Code of conducts should respond to the needs and expectations of the customers. According to the standard, information concerning the code should be accurate, not misleading, capable of being verified and in compliance with relevant statutory and regulatory requirements. Moreover continual improvement of the code with the use of reporting on the actions and decisions of the organization with respect to its code, should be a permanent objective of the organization (ISO 10001).

The investigation is focused on the spa/leisure service sector because previous literature that studies the formalization (in terms of standards and models implemented by companies) of quality promises as a tool for customer satisfaction in this industry has not been found.

${ }^{23}$ B. Dee, S. Karapetrovic, K. Webb, As Easy as 10001,2,3, Quality Progress, 3(6), 41-48, 2004; S. Karapetrovic, IMS: Focus on ISO 10000 Augmentative Standards, "International Journal Total Quality Management and Excellence”, 36(1-2), 1-8, 2008.

${ }^{24}$ ISO 10002 (2004). Quality Management - Customer Satisfaction - Guidelines for Complaints Handling in Organizations, International Organization for Standardization, Geneva, Switzerland.

25 B. Dee, S. Karapetrovic, K. Webb, As Easy as 10001,2,3, Quality Progress, 3(6), 41-48, 2004; S. Hughes, S. Karapetrovic, ISO 10002 Complaints Handling System: a study, International Journal of Quality \& Reliability Management, 23(9), 1158-1175, 2006.

${ }^{26}$ P. Nowicki, A. Simon, P. Kafel, M. Casadesus, Recognition of customer..., 91-105. 
Also, because the knowledge and implementation level of such customer satisfaction standards is very low, it makes sense to study them more in detail and also in a specific sector ${ }^{27}$. In addition, the spa service is one that is provided in a high contact setting, very close to the customer, thus it is interesting to study how the quality promises are used by organizations, because the evaluation of the overall experience by the customer before, during and after the encounter gives strong clues as to the quality of the service provided ${ }^{28}$. Not without significance is the fact, that Spa industry is one of the fastest growing sectors in the tourism industry ${ }^{29}$.

\section{MATERIALS AND METHODS}

\subsection{Methodology}

The aim of this paper is to analyze the ways of quality promises developing and fulfilling as well as to explore whether these actions are formally constituted in terms of standards or other models for code of conducts e.g. ISO 10001.

In this investigation, a case study is defined as, "an empirical inquiry that investigates a contemporary phenomenon within its real-life context; when the boundaries between phenomenon and context are not clearly evident; and in which multiple sources of evidence are used" 30 . The case study approach is useful in exploratory modes of research and can provide initial understanding of particular situations which may then be utilized inductively to create better theory. The case studies analyzed are not meant to be generalizable but rather they are utilized here to gather information about the reality of spa organizations regarding the topic investigated ${ }^{31}$.

Generalization and reasoning within the case study was done with the use of the combination of inductive and abductive mode of reasoning. The main focus of this research was to on understanding the cases not on generalizing the theory ${ }^{32}$.

The research on which this paper draws involved seven case studies of spa organizations from Spain and Poland. The case studies illustrate the organizations' approach to managing complaints and customer satisfaction efficiently. A case study approach was adopted to

${ }^{27}$ S. Karapetrovic, J. Doucette, An Application of Customer Satisfaction Standards in Engineering Management Courses, ASEE Annual Conference \& Exposition, Austin, 2009; A. Simon, S. Karapetrovic, M. Casadesus, On the applications of ISO 10000 customer satisfaction standards in Catalonia, "International Journal of Advanced Quality", 41(1), 23-27, 2013; A. Simon, P. Kafel, P. Nowicki, M. Casadesus, The development of complaints handling standards in spa companies: a case study analysis in Spain, "International Journal for Quality Research", 9(4), 675-688, 2015.

28 C.H. Lovelock, L. Wright, Principles of Service Marketing and Management, N.J., Prentice-Hall, 1999.

${ }^{29}$ K.R. McNeil, E.J. Ragins, Staying in the spa marketing game: Trends, challenges, strategies and techniques, "Journal of Vacation Marketing", 11: 31-39, 2005; A.S. Lu, C. Wu, Effect of Consumption Emotion on Hotel and Resort Spa Experience, "Journal of Travel \& Tourism Marketing", 31(8), 958-984, 2014.

${ }^{30}$ R.K. Yin, Case study research: Design and methods, 4th ed. Thousand Oaks, CA, Sage, 2009.

${ }^{31}$ K.M. Eisenhardt, M.E. Graebner, Theory Building from Cases: Opportunities and Challenges, "Academy of Management Journal", 50(1), 25-32, 2007.

32 R. Johansson, (2003, September). Case study methodology. In the International Conference on Methodologies in Housing Research, Stockholm, Sweden. 
allow causes, processes and consequences of behavior to be investigated ${ }^{33}$. A multiple case study approach was preferred because it enabled the collection of more accurate and comparative data ${ }^{34}$.

Two European countries were chosen for the research in order to compare organizations from countries with different experiences with the implementation of quality management systems. Spain is an old EU country where QMS systems are widely implemented. According to the ISO survey Spain is on the 4th place in Europe in a number of organizations with ISO 9001 certificates. Poland is one of the countries with the average number of registered QMS, ranking 11 place in Europe with ISO 9001 certificates (ISO 2013). Moreover it is one of the post-communist countries, with very different attitude to the management issues. Not without significance was also origin of the authors ${ }^{35}$ and the ease of cultural and linguistic perception. Besides the knowledge about the area researched as well as access to the data had been also undertaken into consideration.

\subsection{Data collection and analysis}

Fieldwork has been a fundamental part of this investigation. The initial contact with the eight case study organizations was established by telephone or by email during the months of January and February 2014, and the interviews were conducted in the first quarter of 2014 in Spain and Poland. However, in the final sample there has only been used 7 case studies. The prerequisite for the selection of a particular spa was existence of formal or informal quality promises in the organizations. This requirement was verified by checking spa websites and advertisements or direct contact with spa personnel (phone calls, visits, emails). Regarding the interviews with the managers for quality/customer satisfaction, we used a semi-structured questionnaire which included questions about how the organizations dealt with quality promises and whether they used the guidelines of the ISO 10001, ISO 10002 and ISO 10003 standards. While we stuck to our interview protocol, we allowed respondents to answer widely for questions to get more information on the analyzed subject. The interviews consisted of three main parts concerning the code of conduct, complaints handling and dispute-resolution process. All interviews lasted between 40 and 60 minutes and were recorded, transcribed, and included in a case study protocol ${ }^{36}$. Case studies were conducted in national languages (Polish and Spanish). In addition, there secondary data from organization reports, annual results, web pages, academic articles and other company information were collected that the authors had access to when studying the organization and which were available internally and publicly, thus allowing for empirical triangulation of the data.

A within-case interpretation was the first level of data analysis, analyzing each case separately, and compiling a case study history based on the interviews and secondary data ${ }^{37}$.

\footnotetext{
${ }^{33}$ R.K. Yin, Case study research...

${ }^{34}$ R.K. Yin, Case study research...; K.M. Eisenhardt, M.E. Graebner, Theory Building from Cases: Opportunities and Challenges, "Academy of Management Journal", 50(1), 25-32, 2007.

35 A.K. Koźmiński, Anatomy of systemic change polish management in transition, Communist and Post-Communist Studies, 41, 263-280, 2008; G.W. Kołodko, A two-thirds of success. Poland's post-communist transformation 1989-2009, Communist and Post-Communist Studies 42, 325-351, 2009.

${ }^{36}$ R.K. Yin, Case study research...

37 Ibidem.
} 
The second step was a cross-case search for patterns, our second level of interpretation, which involved all of the researchers looking for within-group similarities coupled with intergroup differences ${ }^{38}$. Conducting cross-case analysis has been supported by researchers including Eisenhardt (1989) or Stavros and Westberg (2009) as it increases the validity and reliability of the case-study methodology.

According to this methodology, in the next sections of the paper, we proceed to perform the analysis of the case studies. Because the studied companies did not allow using their names, they have been replaced with the names of mountains ${ }^{39}$.

\section{PRESENTATION AND ANALYSIS OF THE CASE STUDIES}

\subsection{Case organizations characteristics}

In table 1. the organizations included in this investigation and the main characteristics associated with an involvement in quality management issues are presented. The knowledge about quality standards and the use of ISO 10000 series are also presented.

Table 1. Case organizations*

\begin{tabular}{|l|l|l|l|}
\hline & Standards certification & \multicolumn{1}{|c|}{$\begin{array}{c}\text { Knowledge } \\
\text { of ISO 10000 } \\
\text { series }\end{array}$} & \multicolumn{1}{|c|}{ Type of customers } \\
\hline Kilimanjaro & $\begin{array}{l}\text { They had previously had } \\
\text { "Q de calidad" (Spanish } \\
\text { quality certificate for } \\
\text { tourist firms) }\end{array}$ & No & $\begin{array}{l}\text { - Mainly retired people } \\
\text { In second place young couples } \\
\text { and families } \\
\text { - Individual and mainly local }\end{array}$ \\
\hline Aconcagua & $\begin{array}{l}\text { Certificate of Excellence } \\
\text { (Trip Advisor) 2013 }\end{array}$ & No & $\begin{array}{l}\text { - Mainly golfers but also families } \\
\text { and young couples } \\
\text { - Individual and up to 40\% foreign }\end{array}$ \\
\hline Montblanc & ISO 9001 (2014) & $\begin{array}{l}\text { Yes. ISO 10002 } \\
\text { implemented in } \\
\text { another firm of } \\
\text { the group }\end{array}$ & $\begin{array}{l}\text { - Mainly young couples and } \\
\text { families } \\
\text { Secondly, retired people } \\
\text { - Individual and mainly local }\end{array}$ \\
\hline Elbrus & $\begin{array}{l}\text { None. They are planning } \\
\text { to implement ISO 9001. }\end{array}$ & No & $\begin{array}{l}\text { - Mainly retired people } \\
\text { In second place young couples } \\
\text { and families }\end{array}$ \\
\hline K2 & $\begin{array}{l}\text { ISO 9001 (6 years), } \\
\text { GMP }\end{array}$ & No & $\begin{array}{l}\text { - - Middide-aged women } \\
\text { - 100\% individual and direct } \\
\text { - Regular }\end{array}$ \\
\hline
\end{tabular}

${ }^{38}$ K.M. Eisenhardt, M.E. Graebner, Theory Building from Cases: Opportunities and Challenges, Academy of Management Journal, 50(1), 25-32, 2007.

${ }^{39}$ P. Nowicki, A. Simon, P. Kafel, M. Casadesus, Recognition of customer..., 91-105, 2014. 
Table 1 (cd.)

\begin{tabular}{|l|l|l|l|}
\hline & Standards certification & \multicolumn{1}{c|}{$\begin{array}{c}\text { Knowledge } \\
\text { of ISO 10000 } \\
\text { series }\end{array}$} & \multicolumn{1}{c|}{ Type of customers } \\
\hline Lhotse & $\begin{array}{l}\text { None, except internal } \\
\text { network standards. }\end{array}$ & No & $\begin{array}{l}\text { - Mainly young couples and } \\
\text { families } \\
\text { Secondly, middle-aged and older } \\
\text { people } \\
- \text { Individual and mainly tourists } \\
-70 \% \text { individual and direct and } \\
\text { mainly irregular }\end{array}$ \\
\hline $\begin{array}{l}\text { Gasher- } \\
\text { brum }\end{array}$ & ISO 9001 (7 years) & No & $\begin{array}{l}\text { - Mainly middle-aged and older } \\
\text { people } \\
-95 \% \text { individual and direct } \\
\text { - Irregular }\end{array}$ \\
\hline
\end{tabular}

*adapted from P. Nowicki, A. Simon, P. Kafel, M. Casadesus, Recognition of customer...

In four cases, studied organizations had implemented a quality management system according to the ISO 9001 standards, which was confirmed by independent third party certification bodies. Other studied organizations had also experience in the field of quality management e.g. certificate of excellence or implementation of internal network management standards. In spite of the fact that organizations are familiar with quality management standards, only one was aware of the existence of standards from the ISO 10000 series. It was a Spanish organization which implemented ISO 10002 standard in another firm of the group. No one from the group of respondents had the opportunity to become acquainted with ISO 10001 standards. Little knowledge of the existence and requirements of ISO 10000 series of standards in studied cases has also been indicated in other researches ${ }^{40}$.

\subsection{Code of conducts formalization in procedures}

Quality promises are widely used by organizations, but formalization of the promises through their recording in leaflets, on website or in other documents that are available for customers is not as common. Only in three studied organizations there were formally documented quality promises. In Kilimanjaro and Aconcagua they were available on websites and in the case of $\mathrm{K} 2$ in the leaflets. In other four organizations quality promises are used as informal/internal codes. According to quality management systems, the documentation of an organization shall include the documents needed by the organization to ensure the effective planning, operation and control of its processes ${ }^{41}$. In two cases there were no documented procedures for the codes of conduct. All the actions associated with the fulfillment of the quality promises are done by the spa staff based on previous manager training. In other 5 cases, there were formal procedures which describe the process of fulfillment of quality promises. In two cases there were separate instructions, in the remaining

${ }^{40}$ P. Kafel, Normy wspomagajace systemy zarzadzania - wykorzystanie w organizacjach, ABC Jakości. Quality Review, 1(81), 15-19, 2015.

${ }^{41}$ ISO 9001 (2015). Quality Management Systems - Requirements, International Organization for Standardization, Geneva, Switzerland. 
three cases, formal procedures were implemented as a part of other procedures e.g. in $\mathrm{K} 2$ it was a medical procedure instruction.

One important factor that has influence to the code of conduct formalization, is the frequency of their use. Quality representatives were asked about the frequency of reporting the claims in the last 12 months. In one of the organizations, the Aconcagua, they believed that the number of claims regarding the code was directly correlated with customer satisfaction and thus, they strongly encouraged their customers to make their claims and provide feedback on the codes. In spite of the well-advertised and available quality promise in $\mathrm{K} 2$, there were no clients' requests in the last 12 months. According to the quality representative, the lack of claims is related with the high quality of service in the spa. Health problems described in the quality promise are rare and can be avoided when good medical practices are used in the organization.

In other cases, clients take the advantage of the code and asked to fulfill the quality promises. The average frequency of clients request is rather low. Obtained data suggest, that in organizations where formal quality promises and formal procedures exist, the number of customer claims is lower than in organizations where informal ones exist. That fact was especially observed in the Aconcagua company, where both types of quality promises exist, and the informal ones are used more often. In table 2 there are data concerning the quality promises in the studied organizations. These observations suggest, that informal quality promises which are more flexible in nature allow better use of quality promises as a marketing tool.

Table 2. Quality promises in organizations

\begin{tabular}{|l|l|c|c|}
\hline & \multicolumn{1}{|c|}{$\begin{array}{c}\text { Customer Satisfaction-Codes } \\
\text { of conduct }\end{array}$} & $\begin{array}{c}\text { Formal } \\
\text { procedures and } \\
\text { documentation } \\
\text { for codes of } \\
\text { conduct }\end{array}$ & $\begin{array}{c}\text { Average frequency of } \\
\text { clients requests concerning } \\
\text { fulfillment of quality } \\
\text { promises in a one year } \\
\text { period of time }\end{array}$ \\
\hline $\begin{array}{l}\text { Kiliman- } \\
\text { jaro }\end{array}$ & $\begin{array}{l}\text { Formal in the web site: Price } \\
\text { promise "if you find the same ser- } \\
\text { vice cheaper in another spa, we'll } \\
\text { give the money back to you" }\end{array}$ & yes & 2 \\
\hline Aconcagua & $\begin{array}{l}\text { Formal in the web site: Price } \\
\text { promise "if you find the same ser- } \\
\text { vice cheaper in another spa, we'll } \\
\text { give the money back to you" } \\
\text { Informal/internal: Beauty treat- } \\
\text { ments "if they don't deliver them } \\
\text { as promised (late or lacking } \\
\text { one treatment because lack of } \\
\text { products) they give one free". }\end{array}$ & yes & 12 \\
\hline Montblanc & $\begin{array}{l}\text { Informal/internal: Opening times } \\
\text { of the spa "if it's not open all the } \\
\text { hours as promised, they give the } \\
\text { customers two hours more of spa" }\end{array}$ & no & \\
\hline
\end{tabular}


Table 2 (cd.)

\begin{tabular}{|c|c|c|c|}
\hline & $\begin{array}{l}\text { Customer Satisfaction-Codes } \\
\text { of conduct }\end{array}$ & $\begin{array}{l}\text { Formal } \\
\text { procedures and } \\
\text { documentation } \\
\text { for codes of } \\
\text { conduct }\end{array}$ & $\begin{array}{l}\text { Average frequency of } \\
\text { clients requests concerning } \\
\text { fulfillment of quality } \\
\text { promises in a one year } \\
\text { period of time }\end{array}$ \\
\hline Elbrus & $\begin{array}{l}\text { Informal/internal: Treatments "If } \\
\text { the treatment not as promised (e.g. } \\
\text { shorter massage that contracted) } \\
\text { a longer massage is offered" }\end{array}$ & no & 2 \\
\hline K2 & $\begin{array}{l}\text { Formal in the leaflets and at the } \\
\text { beginning of the process: Help in } \\
\text { case of health problems "if you } \\
\text { experience any adverse health } \\
\text { effects' after spa services we will } \\
\text { provide free medical assistance } \\
\text { and treatment" }\end{array}$ & $\begin{array}{l}\text { yes (as a part } \\
\text { of other } \\
\text { procedures) }\end{array}$ & 0 \\
\hline Lhotse & $\begin{array}{l}\text { Informal/internal: Beauty treat- } \\
\text { ments "if they don't deliver them } \\
\text { as promised (late or lacking one } \\
\text { treatment because of any issues) } \\
\text { they give another free". }\end{array}$ & $\begin{array}{l}\text { yes (as a part } \\
\text { of other } \\
\text { procedures) }\end{array}$ & 5 \\
\hline $\begin{array}{l}\text { Gasher- } \\
\text { brum }\end{array}$ & $\begin{array}{l}\text { Informal/internal: Treatments "If } \\
\text { the treatment not as promised (e.g. } \\
\text { shorter massage that contracted) } \\
\text { a longer massage is offered" } \\
\text { Beauty treatments "if they don't } \\
\text { deliver them as promised (late or } \\
\text { lacking one treatment, or the cus- } \\
\text { tomer is not satisfied with the ser- } \\
\text { vice) they give another one free". }\end{array}$ & $\begin{array}{l}\text { yes (as a part } \\
\text { of other } \\
\text { procedures) }\end{array}$ & 3 \\
\hline
\end{tabular}

*adapted from P. Nowicki, A. Simon, P. Kafel, M. Casadesus, Recognition of customer...

\subsection{Fulfillment of the main principles of the code of conduct}

In ISO 10001 there are seven customer-focused guiding principles that help in effective code of conduct implementation. The results of fulfillment of principles in the studied organizations are presented in table 3 below, measured in 5 point scale, where the numbers means: 1 - not at all, 2 - little fulfillment, 3 - medium fulfillment, 4 - good fulfillment, 5 - entire fulfillment.

When talking to the representatives of the organizations, some common important points came out regarding the fulfillment of general principles. Despite the earlier lack of knowledge about the ISO 10001 requirements, the fulfillment of almost all general principles were assesed on a medium or higher level. It means that standard requirements are quite intuitive for organizations. In general, the biggest difficulties that organizations had related to the fourth principle - responsiveness. The fulfillment of this principle means that an organization's code should respond to the needs and expectations of its customers. The 
implementation of this principle means that the quality promise should be planned and designed properly. The process of planning and design should contain (ISO 10001):

- objectives achieved by the code,

- needed resources,

- gathering and assessment of preliminary information,

- preparation of draft codes and code procedures,

- preparation of draft performance indicators,

- initial determination of resources,

- preparation of a draft communication plan,

- finalize the code, performance indicators, procedures, resources needs and code communication.

Table 3. Fulfillment of guiding principles from ISO 10001

\begin{tabular}{|l|c|c|c|c|c|c|c|}
\hline Guiding principles & Kilimanjaro & Aconcagua & Montblanc & Elbrus & K2 & Lhotse & Gasherbrum \\
\hline Capacity & 3 & 5 & 4 & 2 & 5 & 3 & 4 \\
\hline Visibility & 4 & 5 & 4 & 3 & 3 & 4 & 3 \\
\hline Accessibility & 5 & 4 & 3 & 3 & 1 & 5 & 3 \\
\hline Responsiveness & 4 & 3 & 4 & 1 & 3 & 3 & 3 \\
\hline Accuracy & 3 & 4 & 3 & 3 & 5 & 4 & 2 \\
\hline Accountability & 4 & 4 & 2 & 1 & 5 & 4 & 3 \\
\hline $\begin{array}{l}\text { Continual } \\
\text { improvement }\end{array}$ & 4 & 5 & 4 & 3 & 3 & 3 & 4 \\
\hline
\end{tabular}

In the studied spas, the process of planning and design of the quality promises was not as formalized as ISO 10001 standard advises. According to the representative of the K2 organization, and also to the Aconcagua quality manager, quality promises are used mainly as a marketing tool and an effort involved to the implementation of quality promise is rather low. It is one of many tools used by spas to convince the customer about the quality of their services.

In three cases, there were established, implemented and maintained quality management systems complaint with ISO 9001 standard. These organizations are more familiar with quality standards and some formal requirements of all management standards e.g. continual improvement or documentation of processes. In general, organizations with implemented QMS are on a higher level of management that organizations without QMS. So it can be assumed that fulfillment of guiding principles of 10001 in organizations that had experience with ISO 9001 is higher than in other spas. In the studied organizations, an average level of guiding principles fulfillment is higher in spas with ISO 9001 than in spas without the ISO 9001 standard.

\subsection{Comparison of Polish and Spanish organizations}

Another factor that can divide the fulfillment of guiding principles, is the spa's country of origin. The organizations chosen for the case studies operated in Poland and Spain. The results of the study do not indicate any significant differences between those two groups of 
organizations according to origin. This statement only relates to the analyzed organizations. In both groups of organizations the knowledge about ISO 10001 standard was minimal. In two Spanish spas there were formal price promises, which were not identified in the Polish case studies. There are three Polish case studies described in the article, but during the preparation of the research any other Polish spa was identified as one with formal price promises. It is possible that the quality promises are different in those two countries due to some cultural differences but this issue needs more profound research.

When comparing the results of the study in the group of organizations with an implemented and certified quality management system, there are similarities between the Polish and Spanish spas. Those companies fulfill the guiding principles of ISO 10001 standard on a similar level.

\section{CONCLUSIONS}

The objectives of this study were to analyze the ways of quality promises developing and fulfilling as well as to explore whether these systems are formally constituted in terms of standards or other models for code of conducts e.g. ISO 10001. The results of this paper suggest that quality promises are widely used by organizations, but formalization of the promises through their recording in leaflets, on website or in other documents that are available for customers is not as common. Although spas use codes of conduct, the knowledge of the codes of conduct models and standards such as ISO 10001 is rather low. In particular, only in one case, representatives of the spa have experience with the ISO 10000 series of standards. In the other cases, the spas representatives were not familiar with those standards at all due to its unpopularity as well as low level of knowledge about it. There is also a need to mention that some requirements has been fulfilled, but without a usage of the described standard.

The results of this paper suggest that the average frequency of clients request of fulfillment of quality promises is rather low. Furthermore, in organizations where there exists formal quality promises and formal procedures, the number of customer claims is lower than in organizations where informal ones exist. Flexibility of informal quality promises offer spas a possibility to use them more widely and more frequently than in case of formal standardized codes.

Another significant aspect taken into account was the fact that the fulfillment of almost all the general principles in the studied spas was assessed on a medium level. There has not been found differences between Polish and Spanish organizations that has been analyzed. The implementation of a Quality management system was recognized as an important factor that had influence on the fulfillment of the guiding principles from the ISO 10001 standard. The companies with implemented and certified ISO 9001 standard were characterized by a better fulfillment for the realization of the promises as well as the codes of conduct. This might be due to the process-based management system coming out form the QMS requirements.

Two main limitations can be highlighted about this study. The first is the usage of seven particular case studies which does not allow the extraction of robust conclusions about the process of quality promises in the organizations. The second main limitation is the fact that the employees interviewed were all part or had responsibilities regarding the processes of quality promises handling as a part of the quality management system, thus their vision 
could be biased. For future research, interviews with employees from all the levels could enrich our findings.

The last but not least conclusion is that a results of this research may be used by spas managers as a implications for the companies, which can help them in development of the company's strategy in the customer service areas. In particular it is advised to implement the ISO 10001 standard which will make possible to increase the level of customer service in the spas.

\section{REFERENCES}

[1] Ansoleaga R.S., EFQM excellence model implementation in Metro Bilbao. Dyna 82, 6-8, 2007.

[2] Bayo-Moriones A., Merino-Díaz-de-Cerio J., Escamilla-de-León S.A., Selvam R.M., The impact of ISO 9000 and EFQM on the use of flexible work practices, "International Journal of Production Economics", 130(1), 33-42, 2011.

[3] Briscoe J.A., Fawcett S.E., Todd R.H., The implementation and impact of ISO 9000 among small manufacturing enterprises, "Journal of Small Business Management", 43(3), 309-330, 2005.

[4] Chattopadhyay S.P., Improving the speed of ISO 14000 implementation: a framework for increasing productivity, "Managerial Auditing Journal”, 16(1), 36-40, 2001.

[5] Chen C.Y., Wu G.S., Chuang K.J., Ma C.M., A comparative analysis of the factors affecting the implementation of occupational health and safety management systems in the printed circuit board industry in Taiwan, "Journal of Loss Prevention in the Process Industries", 22(2), 210-215, 2009.

[6] Crompton J.L., Love L.L., The Predictive Validity of Alternative Approaches of Evaluating Quality of a Festival, "Journal of Travel Research", 34, 11-24, 1995.

[7] De Cremer D, van Dijk E., Pillutla M.M., Explaining unfair offers in ultimatum games and their effects on trust: an experimental approach, "Business Ethics Quarterly", 20(1), 107-126, 2010.

[8] Dee B., Karapetrovic S., Webb K., As Easy as 10001,2,3, Quality Progress, 3(6), 41-48, 2004.

[9] Eisenhardt K.M., Graebner M.E., Theory Building from Cases: Opportunities and Challenges, "Academy of Management Journal", 50(1), 25-32, 2007.

[10] Fabien L., Making promises: the power of engagement, "Journal of Services Marketing", Vol. 11(3), 206-214, 1997.

[11] Girard M., Mullet E., Callahan S., The mathematics of forgiveness, "American Journal of Psychology", 115, 351-375, 2002.

[12] Hughes S., Karapetrovic S., ISO 10002 Complaints Handling System: a study, "International Journal of Quality \& Reliability Management”, 23(9), 1158-1175, 2006.

[13] ISO (2013). The ISO Survey of Certifications - 2013, Geneva, Switzerland: International Organization for Standardization.

[14] ISO 10001 (2007). Quality Management - Customer Satisfaction - Guidelines for Codes of Conduct, International Organization for Standardization, Geneva, Switzerland.

[15] ISO 10002 (2004). Quality Management - Customer Satisfaction - Guidelines for Complaints Handling in Organizations, International Organization for Standardization, Geneva, Switzerland. 
[16] ISO 10003 (2007). Quality management -Customer satisfaction - Guidelines for dispute resolution external to organizations, International Organization for Standardization, Geneva, Switzerland.

[17] ISO 9001 (2015). Quality Management Systems - Requirements, International Organization for Standardization, Geneva, Switzerland.

[18] Johansson R. (2003, September). Case study methodology, In the International Conference on Methodologies in Housing Research, Stockholm, Sweden.

[19] Kafel P., Normy wspomagajace systemy zarzadzania - wykorzystanie w organizacjach, „ABC Jakości. Quality Review”, 1(81), 15-19, 2015.

[20] Karapetrovic S., IMS: Focus on ISO 10000 Augmentative Standards, "International Journal - Total Quality Management and Excellence”, 36(1-2), 1-8, 2008.

[21] Karapetrovic S., Doucette J., An Application of Customer Satisfaction Standards in Engineering Management Courses, ASEE Annual Conference \& Exposition, Austin 2009.

[22] Kołodko G.W., A two-thirds of success. Poland's post-communist transformation 1989-2009, Communist and Post-Communist Studies 42, 325-351, 2009.

[23] Kotler P., Keller K., Marketing Management, 12th ed, Prentice Hall, 2006.

[24] Kozminski A.K., Anatomy of systemic change polish management in transition, Communist and Post-Communist Studies, 41, 263-280, 2008.

[25] Kucukusta D., Pang L., Chui S., Inbound Travelers' Selection Criteria for Hotel Spas in Hong Kong, Journal of Travel \& Tourism Marketing, 30(6), 557-576, 2013.

[26] Lovelock C.H., Wright L., Principles of Service Marketing and Management, N.J., Prentice-Hall 1999.

[27] Lu A.S., Wu C., Effect of Consumption Emotion on Hotel and Resort Spa Experience, "Journal of Travel \& Tourism Marketing", 31(8), 958-984, 2014.

[28] Luo X., Consumer negative voice and firm-idiosyncratic stock returns, "Journal of Marketing”, 71(3), 75-88, 2007.

[29] Luo X., Homburg C., Neglected outcomes of customer satisfaction, “Journal of Marketing”, 71(2), 133-149, 2007.

[30] Martínez-Costa M., Martínez-Lorente A.R., Choi T.Y., Simultaneous consideration of TQM and ISO 9000 on performance and motivation: an empirical study of Spanish companies, "International Journal of Production Economics", 113(1), 23-29, 2008.

[31] McCullough, M.E., Rachal, K.C., Sandage S.J., Worthington E.L., Brown S.W., Hight T.L., Interpersonal forgiving in close relationships. II. Theoretical elaboration and measurement, "Journal of Personality and Social Psychology", 75, 1586-1603, 1998.

[32] McNeil K.R., Ragins E.J., Staying in the spa marketing game: Trends, challenges, strategies and techniques, "Journal of Vacation Marketing", 11: 31-39, 2005.

[33] Mo J.P., \& Chan A.M., Strategy for the successful implementation of ISO 9000 in small and medium manufacturers, "The TQM magazine", 9(2), 135-145, 1997.

[34] Nowicki P., Kafel P., Sikora T., Assessment of integrated management system policy, Economy and Management, Wydawnictwo Politechniki Białostockiej, 105-112, 2012.

[35] Nowicki P., Simon A., Kafel P., Casadesus M., Recognition of customer satisfaction standards of ISO 10000 family by spa enterprises - a case study analysis, "Revista TMQ, Techniques, Methodologies and Quality", 5, 91-105, 2014.

[36] Poksinska B., Jörn Dahlgaard J. \& Eklund J. A., Implementing ISO 14000 in Sweden: motives, benefits and comparisons with ISO 9000, "International Journal of Quality \& Reliability Management”, 20(5), 585-606, 2003. 
[37] Sampaio P., Saraiva P., \& Guimarães Rodrigues A., ISO 9001 certification research: questions, answers and approaches, "International Journal of Quality \& Reliability Management", 26(1), 38-58, 2009.

[38] Schniter E., Sheremeta R.M., Sznycer D., Building and rebuilding trust with promises and apologies, "Journal of Economic Behavior \& Organization", 94, 242-256, 2013.

[39] Simon A., Kafel P., Nowicki P., Casadesus M., The development of complaints handling standards in spa companies: a case study analysis in Spain, "International Journal for Quality Research", 9(4), 675-688, 2015.

[40] Simon A., Karapetrovic S., Casadesus M., On the applications of ISO 10000 customer satisfaction standards in Catalonia, "International Journal of Advanced Quality", 41(1), 23-27, 2013.

[41] Smith A.K., Bolton R.N., Wagner J., A model of customer satisfaction with service encounters involving failure and recovery, "Journal of Marketing Research", 36(3), 356-372, 1999.

[42] Stavros C., Westberg K., Using Triangulation and Multiple Case Studies to Advance Relationship Marketing Theory, "Qualitative Research: An International Journal", 12(3), 307-320, 2009.

[43] Tomlinson E.C., The impact of apologies and promises on post-violation trust: The mediating role of interactional justice, "International Journal of Conflict Management", 23(3), 224-247, 2012.

[44] Urbonavicius S., ISO system implementation in small and medium companies from new EU member countries: A tool of managerial and marketing benefits development, "Research in international business and finance", 19(3), 412-426, 2005.

[45] Viada-Stenger M.C., Balbastre-Benavent F., Redondo-Cano A.M., The implementation of a quality management system based on the $Q$ tourist quality standard. The case of hotel sector. Service Business, 4, 177-196, 2010.

[46] Yin R.K., Case study research: Design and methods, 4th ed. Thousand Oaks, CA, Sage, 2009.

[47] Zeng S.X., Tian P., Tam C.M., Overcoming barriers to sustainable implementation of the ISO 9001 system, "Managerial Auditing Journal”, 22(3), 244-254, 2007.

\section{DEKLARACJE JAKOŚCI. CZY FIRMY STOSUJĄ KODEKSY POSTĘPOWANIA? NA PRZYKŁADZIE BRANŻY SPA}

Celem niniejszego artykułu jest analiza sposobów opracowywania i wypełniania obietnic jakościowych oraz badanie, czy działania te są formalnie ukonstytuowane. W celu porównania organizacji do badań wybrano dwa kraje europejskie o różnych poziomach doświadczenia związanego z wdrażaniem systemów zarządzania jakością. Pierwszym z nich jest Hiszpania, jako tzw. stary kraj członkowski UE, w którym systemy QMS są szeroko stosowane. Zgodnie z danymi pochodzącymi z ISO Survey, Hiszpania znajduje się na czwartym miejscu w Europie pod względem organizacji posiadających certyfikaty ISO 9001. Z kolei Polska, jako „,nowy” kraj członkowski UE jest jednym z krajów o średniej liczbie zarejestrowanych SZJ, zajmując 11. miejsce w Europie $\mathrm{z}$ certyfikatami ISO 9001. W celu realizacji wyżej wymienionego celu badania, przeprowadzono siedem studiów przypadków organizacji uzdrowiskowych (spa) w branży wypoczynkowej z Polski i Hiszpanii (odpowiednio trzy i cztery). Studia przypadków ilustrują podejście organizacji do zarządzania obietnicami/deklaracjami dotyczącymi jakości. Metoda studium przypadku została wybrana ze względu na specyfikę analizowanego przedmiotu i sposób prowadzonej działalności. Wyniki pokazują, że 
wszystkie siedem organizacji wdrożyło pewne mechanizmy, aby sprostać obietnicom związanym z jakością. Wyniki sugerują również, że obietnice dotyczące jakości są szeroko stosowane przez organizacje, ale sformalizowanie obietnic poprzez ich zapisywanie w ulotkach, na stronie internetowej lub $\mathrm{w}$ innych dokumentach dostępnych dla klientów nie jest tak powszechne. Analiza wykazała również, że spełnienie wytycznych normy ISO 10001 jest na średnim poziomie i istnieją możliwości ich poprawy.

Słowa kluczowe: jakość obsługi, satysfakcja klienta, obietnice jakości, ISO 10001.

DOI: $10.7862 /$ rz.2017.hss.47

Przestano do redakcji: styczeń $2016 r$.

Przyjęto do druku: wrzesień 2017 r. 
